\title{
RELATIVE EFFECTS OF MARKETING EFFECTIVENESS DIMENSIONS ON FIRM PERFORMANCE: AN EMPIRICAL ANALYSIS WITH A MULTI-INDUSTRY SAMPLE
}

\author{
MISRA ÇAĞLA GÜL* \\ Işık University
}

\begin{abstract}
The aim of this study is to understand the influence of marketing operational efficiency and marketing system effectiveness on firm performance dimensions. Marketing operational efficiency and marketing system effectiveness are two dimensions of marketing effectiveness derived as a result of the exploratory factor analysis performed on the data. Firm performance dimensions used in the study are overall performance, ROI, percentage of new product sales, change in market share, and sales growth, all measured relative to competitors. Multiple respondent firm level data are collected through a survey of 74 firms operating in a variety of industries, resulting in 296 individual surveys. Findings indicate that marketing operational efficiency, a set of short-term, operational dimensions, positively influences all of the firm performance dimensions. On the other hand, marketing system effectiveness, measuring longer-term, strategic factors, does not have such an impact.
\end{abstract}

Key words: marketing operational efficiency, marketing effectiveness, firm performance, marketing system effectiveness, marketing strategy, multivariate regression.

PAZARLAMA ETKİNLİĞI BILLEŞENLERININN ŞİRKET PERFORMANSI ÜZERINDEKI ETKISİ: ÇOKLU ENDÜSTRI ÖRNEKLEMIYLE GÖRGÜL

\section{ANALIZ}

$\ddot{O Z E T}$

Bu çalışmanın amacı pazarlama operasyonel verimliliğinin ve pazarlama sistem etkinliğinin şirket performans göstergeleri üzerindeki etkisini anlamaktır. Pazarlama operasyonel verimliliği ve pazarlama sistem etkinliği, pazarlama etkinliğinin açıklayıcı faktör analizi sonucu elde edilen iki bileşenidir. $\mathrm{Bu}$ çalışmada kullanılan şirket performans göstergeleri genel performans, yatırımların geri dönüş oranı, yeni ürün satış yüzdesi, pazar payı değişim miktarı, ve satış büyümesidir. Araştırma kapsamında, çeşitli sektörlerde faaliyet gösteren 74 şirketten 296 anket toplanmışır. Bulgular, pazarlama operasyonel verimliliğinin, yani kısa dönem, operasyonel faktörlerin, bütün şirket performans göstergelerini olumlu olarak etkilediğini göstermektedir. Ancak, daha uzun dönemli, stratejik boyutları kapsayan pazarlama sistem etkinliğinin şirket performans göstergeleri üzerinde anlamlı bir etkisi bulunmamıştır.

Anahtar kelimeler: pazarlama operasyonel verimliliği, pazarlama etkinliği, pazarlama sistemi etkinliği, şirket performansı, çok boyutlu regresyon analizi.

* Mısra Çağla Gül is an Assistant Professor in the Management Department at Işık University, 34980, Şile, Istanbul, Turkey. E-mail: misragul@isikun.edu.tr 
Marketing and firm performance relationship has been a popular stream of research in the marketing and management academia. Many researchers have attempted to address the issue of how different aspects of marketing influence indicators of business performance such as market share, sales growth, marketing effectiveness and ROI (e.g. Narver and Slater, 1990; Yılmaz, Alpkan and Ergun, 2005).

There is a great variety of results in the research done in this area. This does not, however, change the fact that this research stream has created a set of findings that is rich and interesting. Issues of perception, possibly context, and differences in measurement and methodology may be the reasons for this variation in results. Inconsistencies may also be due to the multidimensional nature of the performance construct (Cameron, 1978; Chakravarthy, 1986). It appears that the fundamental linkages between marketing and performance have yet to be explored and given further support.

The purpose of this study is to shed more light on this issue by studying the nature of the relationship between marketing effectiveness and firm performance. Specifically, the study focuses on two dimensions of marketing effectiveness, marketing operational efficiency and marketing system effectiveness; individually it investigates their relative effects on several firm performance dimensions.

These two dimensions have been extracted as a result of the exploratory factor analysis conducted on Webster's (1995) original marketing effectiveness scale. This research is unique in the sense that the measure fell under only two factors as opposed to the original four factors. In addition, this research studies the relationship of the firm performance dimensions separately with marketing system effectiveness and marketing operational efficiency.

The study starts with a theoretical background on the constructs, followed by model development and research methodology. Findings are explained along with a discussion section on theoretical and managerial implications. Finally, limitations of the study are discussed and future directions for research are suggested.

\section{MARKETING EFFECTIVENESS}

Marketing effectiveness has been discussed in the literature frequently due to its link with valuable organizational outcomes (Webster, 1995). However, a few conceptual measures of the construct exist in the literature. According to Kotler (1977), the first requirement of effective marketing is that key managers recognize the primacy of studying the market, distinguishing the many opportunities, selecting the best sections of the market to serve, and gearing up to offer superior value to the chosen customers in terms of their needs and wants. Next, the organization should be staffed so that it will be able to carry out marketing analysis, planning, implementation, and control. Third, effective marketing calls for managers to have adequate information for planning and allocating resources properly to different markets, products, territories, and marketing tools. Marketing effectiveness depends also on whether management can design a profitable strategy. Lastly, marketing plans do not yield desirable results unless they are efficiently carried out at various levels of the organization (Kotler, 1977). Considerable attention has been given to the need for firms to increase their level of marketing effectiveness and capabilities (Reisberg, 1990; Webster, 1988; Appiah-Adu et al., 2001; Moore and Fairhurst, 2003). Appiah-Adu et al. (2001) argued that it is necessary to identify the importance of studying the market, 
recognizing the numerous opportunities, selecting the most appropriate segments of the market to operate in and endeavoring to offer superior value to meet the selected customer's needs and wants. They further argue that marketing effectiveness depends upon managerial competencies such as the manager's ability to design and implement profitable strategies. Nwokah and Ahiauzu (2008) also state that managerial competencies lead to marketing effectiveness. The marketing operational efficiency scale includes items that measure managerial competency related items (see the Appendix).

In order to develop a valid and reliable measurement of marketing effectiveness for service firms, Webster (1995) has refined the framework of marketing effectiveness that was originally developed by Kotler (1977). Webster's framework consists of four dimensions of marketing effectiveness: operational efficiency, customer philosophy, adequate marketing information, and strategic orientation. Recently, Leisen, Lilly and Winsor (2002) defined the dimensions of marketing operational efficiency and customer philosophy to be internal and external marketing effectiveness, respectively. The dimensions of adequate marketing information and strategic orientation were classified as a mix of marketing effectiveness both internal and external.

Research suggests that the marketing performance and effectiveness of a firm is very difficult to measure (O'Sullivan and Abela, 2007; Clark and Amber, 2001; Doyle, 2000). Marketing performance measurement is the measurement of "the relationship between marketing activities and business performance" (Clark and Amber, 2001). This study is an attempt to shed further light on this relationship. It is also found that the ability of a firm to measure its marketing performance positively impacts its overall performance (Rao and Brahadwaj, 2008; O'Sullivan, Abela and Hutchinson, 2009), since marketing performance measurement effort is a good indicator of the importance given to marketing effectiveness in an organization, again suggesting a strong link between marketing effectiveness and firm performance.

This study utilizes an adaptation of Webster's (1995) marketing effectiveness scale because this scale is one of the most comprehensive and reliable measures of the construct to this day, taking into account a number of dimensions such as marketing operational efficiency, customer philosophy, adequate marketing information, and cultural orientation.

\section{FIRM PERFORMANCE}

In investigating the research questions, it is essential to recognize the multidimensional nature of the performance construct (Cameron, 1978; Chakravarthy, 1986). Mentzer and Matsuno (2000) argue that research that considers only a single dimension or a narrow range of the performance construct (e.g., multiple indicators of profitability) may result in misleading descriptive and normative theory building.

There is a variety of research in this area that study financial and nonfinancial measures of firm performance. Nath et al. (2010) use profitability, i.e. operating profit, while measuring firm performance. Other financial indicators such as total sales and growth of sales have also been used in the literature (Slater and Narver, 1994; Greenley, 1995; Matsuno and Mentzer, 2000). Non-financial indicators such as the relative market share have also been used (Day, 1977; Panigyrakis and Theodoritis, 2009) 
Both objective and subjective measures of firm performance have been researched in the past. In their research on studying the relationship between marketing performance measurement ability and firm performance, O'Sullivan and Abela (2007) measured firm performance using both a subjective performance measure and objective secondary data on ROA and stock returns of the sample firms. However, use of subjective, comparative measures of firm performance is more common in the literature (Conant et al., 1993; Van Egeren and O'Connor, 1998; Panigyrakis and Theodoritis, 2009).

In addition, the use of both financial and non-financial indicators is a better approach when measuring the overall performance of the firm (Venkatraman and Ramanujam, 1986). This study adopts both financial and non-financial subjective indicators of firm performance (change in relative market share, relative sales growth, relative ROI, relative percentage of sales from new products, and overall relative performance).

\section{RESEARCH MODEL}

Based on the literature review, the conceptual model below (Figure 1) is proposed. All of the relationships in the conceptual model are expected to be positive, therefore we are not stating individual hypotheses, but, in general, we are exploring the impacts of marketing effectiveness dimensions on indicators of firm performance.

Figure 1

\section{Conceptual Model}

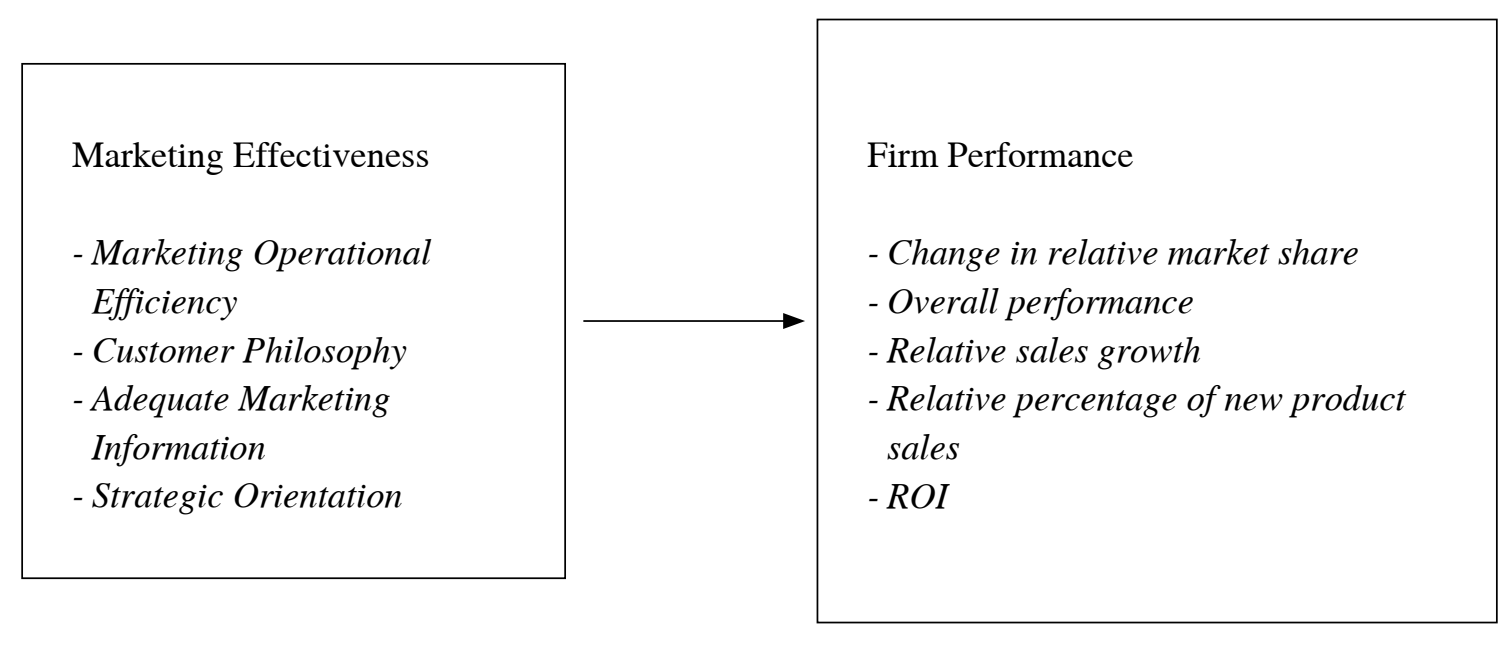

METHODOLOGY

\section{Data Collection and Analysis}

Data collection was done through direct mail survey administration. The scales used in the questionnaire were adaptations. Questionnaire items were pretested after having been translated into Turkish 
(Churchill and Iacobucci, 2005). Five marketing executives were used for the pretest. Electronic and regular mail methods were used to send the instrument to desired prospective respondents, most of whom were middle or upper level managers in business firms. A cover letter was included along with the questionnaire. The actual questionnaire items used can be found in the Appendix.

Data were analyzed using multivariate regression analysis. In addition, correlation analysis was conducted and descriptive statistics were studied.

\section{Sampling}

The study was carried out across multiple industries. Data was collected from multiple informants with different responsibilities for each firm. Multiple informants were used in this study since using multiple informants improved the quality of response data and thereby the validity of research findings in an organizational setting (Van Bruggen, Lilien, and Kacker, 2002). The unit of analysis in this research was the individual firm. A purposive convenience sampling procedure was applied in which sample elements are handpicked because it is expected that they can serve the purpose of the research better (Churchill and Iacobucci, 2005). The population elements of the research were purposively selected among managers and directors and other level employees who could assess the constructs in question. The criteria for sample selection were (1) being for-profit with at least one product/service, and (2) having thirty or more employees with varying responsibilities. Thirty employees were selected as the minimum number of employees. The reason was that this size was large enough to allow for an organization to have a formal organizational structure with basic departments, a necessity for a multiple informant study, and was small enough to help with the difficulties of multiple informant data collection. Multiple informant data collection is difficult since it requires either more than one contact from each firm that meets the requirements of the study or that the key informant finds and contacts other qualified informants in each firm, both of which take extra time and effort. Consistent with past research, both marketing managers and other department managers are included in the sample (Baker and Sinkula, 1999). Snowball effect (Churchill and Iacobucci, 2005) has been used to increase the sample size in which an initial set of firms with desirable characteristics was contacted and asked to identify others that met the research criteria. Our contact person for each firm, an upper level marketing/sales manager, was designated as the key informant for that firm. Key informants were given the cover letter that explained how the questionnaires were to be filled out and by how many people at what levels and functions. These key informants then contacted the employees in the firm that met the criteria for this research. E-mail and telephone follow-ups were conducted. 120 firms were contacted. Of these, 74 firms filled the questionnaires with multiple respondents resulting in a firm level response rate of $62.5 \%$. Although a lower response rate is generally true; this high level of response was due to the selection of the purposive sampling of key informants within a firm, and to close follow-up.

A total of 296 questionnaires were received from 74 companies resulting in an average of 4 questionnaires per firm. Data were aggregated to firm level by averaging key informant responses for each firm. Firms in the sample have 755 employees on the average. The sample includes old and established firms as well as new companies. Table 1 and Table 2 show firm and respondent characteristics, respectively. 
Table 1

Firm Characteristics

\begin{tabular}{cllll}
\hline $\begin{array}{l}\text { Avg \# of Years } \\
\text { in Business }\end{array}$ & $\begin{array}{l}\text { Avg \# of } \\
\text { Employees }\end{array}$ & Industry & Operational Presence & Origin \\
\hline & & $44 \%$ Service & $48 \%$ Multinational & $37 \%$ Foreign \\
& 755 & $\begin{array}{l}56 \% \text { Physical Goods/ } \\
\text { Manufacturing }\end{array}$ & $53 \%$ Just Turkey & $64 \%$ Turkish \\
\hline
\end{tabular}

Table 2

Respondent Characteristics

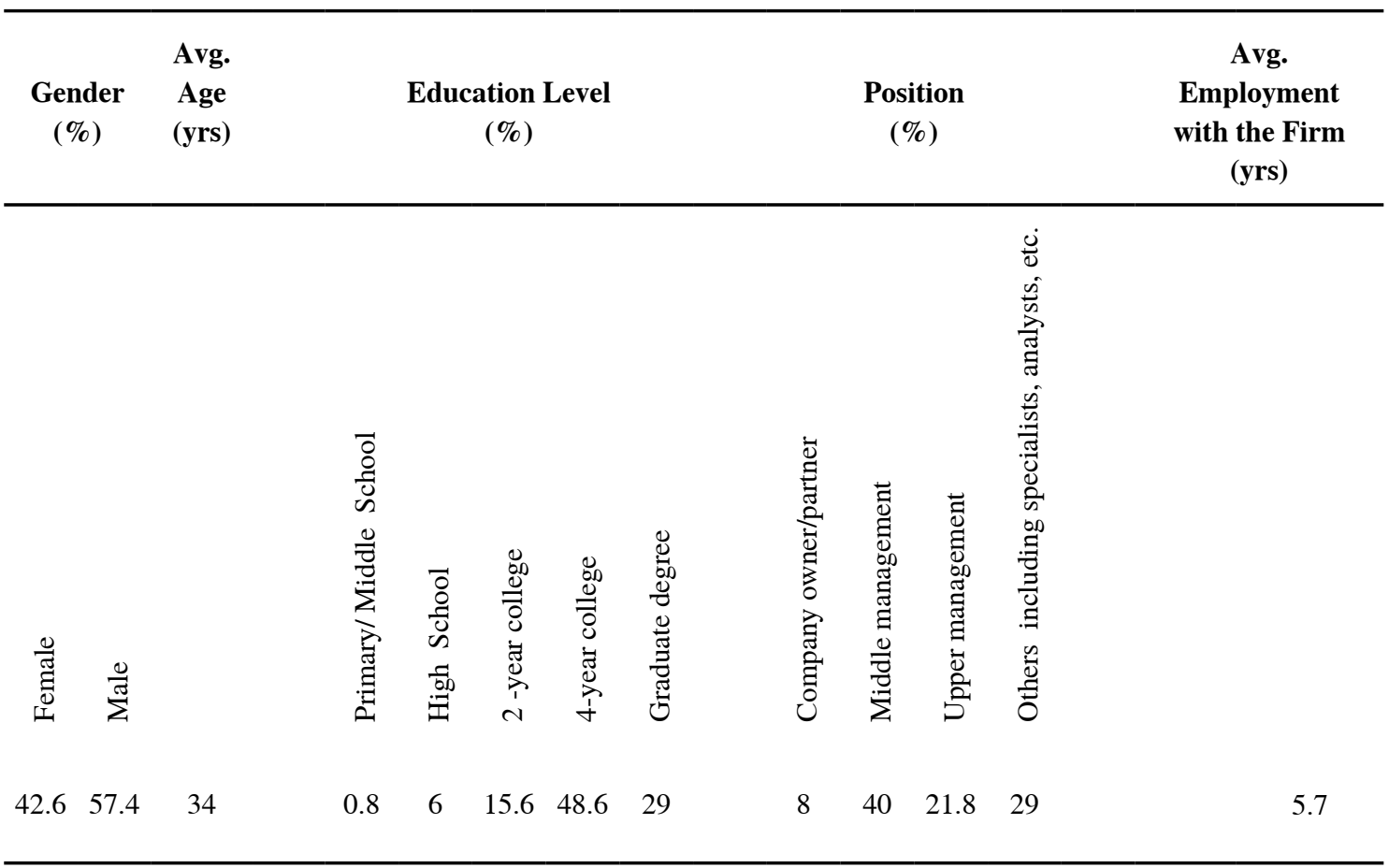

\section{Measures}

Marketing effectiveness was measured using Webster's (1995) 5-point Likert type scale. This scale has 18 items tapping into four dimensions of marketing effectiveness. These dimensions include: 
a. operational efficiency (6 items), that is, how marketing resources are used and marketing function is carried out,

b. customer philosophy ( 5 items), that is, the customer centricity of the firm,

c. adequate marketing information (4 items), that is, information regarding the market, the customer, and

d. the cost effectiveness of marketing activities, and strategic orientation ( 3 items), that is, the strategic and marketing planning dimension.

An exploratory factor analysis was conducted on this measure. Unlike Webster's solution, however, all items loaded on only two factors which we labeled marketing operational efficiency and marketing system effectiveness.

The factors were named based on the items they encompassed. Marketing operational efficiency items relate to the governing board's commitment, its ability to react, its communication, and its research allocation ability. There are also items regarding customer satisfaction monitoring and customercentric organizational design which are also related to operational and implementative aspects of marketing. In addition, most of the items that fell under this factor are consistent with the operational efficiency dimension in Webster's (1995) original measure.

The marketing system effectiveness items include statements that have a more strategic look, such as the existence of a holistic marketing view, marketing cost-effectiveness, marketing research, market planning, and marketing strategy. Due to the system-related and longer-term items under this factor, it was named marketing system effectiveness. Consequently, the effects of these two dimensions only were included in the forthcoming analysis. Internal consistency estimates for these dimensions are .86 and .89 , respectively.

Regarding firm performance, as noted before, a subjective measure was chosen for a variety of reasons. First, firms are often very reluctant to provide "hard" financial data (Fiorito and LaForge, 1986). It was, therefore, felt that more complete financial information could be obtained with a subjective measure. Second, objective financial data on the sampled firms might not be publicly available, making it impossible to check the accuracy of any reported financial performance figures. Third, assuming that accurate financial data were reported, such data for some firms might be difficult to interpret (Cooper, 1979). Finally, absolute scores on financial performance criteria are affected by industry-related factors (Sapienza, Smith, and Cannon, 1988). Given the multi-industry nature of this study, direct comparison of objective financial data could be misleading.

The firm performance scale chosen was a 7-point Likert type scale, and a single item measure was used for each of the five firm performance dimensions.

The measures used in this study can be found in the Appendix. Also, reliability analysis results for all measures used in this study are shown in Table 4. 


\section{RESULTS}

\section{Underlying Assumptions}

Before analysis of the data, the underlying assumptions, linearity, homoscedasticity, normality, and multicollinearity were checked. Linearity was assessed through the residual plots, the studentized residuals versus the predicted values. The residual plots did not exhibit any nonlinear pattern to the residuals. Homoscedasticity was checked using scatter plots. The plots showed no pattern of increasing or decreasing residuals, indicating homoscedasticity. Normality assumption was checked both by a visual examination of the normal probability plots of the residuals and by skewness statistics. Normality plots for each dependent variable shows a diagonal line with no significant departures, indicating a normal distribution. Also, the skewness statistic is less than double its error term for both of the independent variables (.533 with an error term of .282 for marketing system effectiveness, and .483 with an error term of .279 for operational efficiency), which suggests normality (Hair, Anderson, Tatham, and Black, 1998). Finally, multicollinearity was checked with the variance inflation factor (VIF). The highest VIF value was 1.66 , which is less than 10 , the common cutoff threshold (Hair, Anderson, Tatham, and Black, 1998), indicating very low levels of collinearity.

\section{Confirmatory Factor Analysis for Scale Validation}

The procedures used in this research to validate the measures were assessments of convergent and discriminant validity. Proposed factor solutions extracted in exploratory factor analysis were tested for goodness-of-fit. AMOS 4.0 was used in the estimation of the confirmatory measurement model. Findings of the analysis are summarized in Table 3.

Table 3

Confirmatory Factor Analysis on Model Constructs

Model fit: $X^{2} 204.252$ df $68, X^{2} /$ df 2.993

CFI .920, RMSEA .0790

\begin{tabular}{lcc}
\hline Factor & Item t-value & Avg Variance Extracted \\
\hline & 5.10 & \\
Operational & 4.14 & .502 \\
Efficiency & 5.01 & \\
& 5.36 & \\
& 5.14 & .497 \\
Marketing System & 4.65 & \\
Effectiveness & 8.67 & \\
& 5.65 & \\
& 7.40 & \\
\hline
\end{tabular}


When the overall model fit of construct dimensions is reviewed, it can be seen that the items specified for each dimension represent that dimension reasonably well with above the threshold levels for $\mathrm{X}^{2} / \mathrm{df}(<3)$, CFI (>.90), and RMSEA(<.08) (Hair, Anderson, Tatham and Black, 1998). In addition, all items loaded significantly on their respective constructs (with the lowest t-value being 4.14 , significant at $\mathrm{p}<.05)$, providing support for convergent validity.

For each of the factors, average variance extracted (AVE) was computed to check for discriminant validity. AVE was equal to or greater than the threshold value of .50 (Fornell and Larcker, 1981) for both factors (see Table 3). In addition, for each pair of constructs, AVE exceeds the pairwise correlations. Consequently, discriminant validity was obtained for the measure.

\section{Correlations and Descriptive Statistics}

As can be seen in Table 4, when the bivariate relationships are reviewed, the antecedent variables are observed to be significantly correlated with all five performance dimensions, except for the nonsignificant correlation coefficient linking marketing system effectiveness with relative performance of new product sales.

The correlations linking marketing operational efficiency with performance dimensions are generally higher in magnitude than those of marketing system effectiveness. In addition, both antecedents are correlated most strongly with ROI and relative sales growth.

The antecedent variables are also significantly correlated with each other. Even though the high correlation among antecedent variables commonly point to a possible multicollinearity problem, as discussed in the assumptions section above, multicollinearity was checked and very low levels of collinearity were detected. In addition, correlations among all five performance dimensions are significant (see Table 4). In terms of performance dimensions, the correlations with the highest magnitude are between change in relative market share, overall performance and ROI, the highest being between change in relative market share and overall performance.

Marketing operational efficiency has a mean of 3.79 (out of 5) which suggests that the managers of responding firms believe that they have efficient operations in marketing. Marketing system effectiveness mean, however, is closer to the neutral point (3.30), and has a higher standard deviation (.70). This is an indication that the firms included in this study vary substantially in terms of perceived marketing system effectiveness.

The operationalization of firm performance variables ranges from level 1 to 7,1 being significantly worse than competitors, and 7 being significantly better than competition. Therefore, the observed means ranging between 4.75 and 5.22 suggest that, on average, firms perceive themselves as being more successful than their competitors in the past three years in terms of market share, sales growth, ROI, new product sales, and overall performance (see Table 4). Also, standard deviation figures ranging from .99 to 1.13 suggest that some firms felt neutral about their success relative to their competitors, and some felt strongly about their superiority in terms of the performance indicators mentioned above. Descriptive statistics for each variable can be found in Table 4 . 


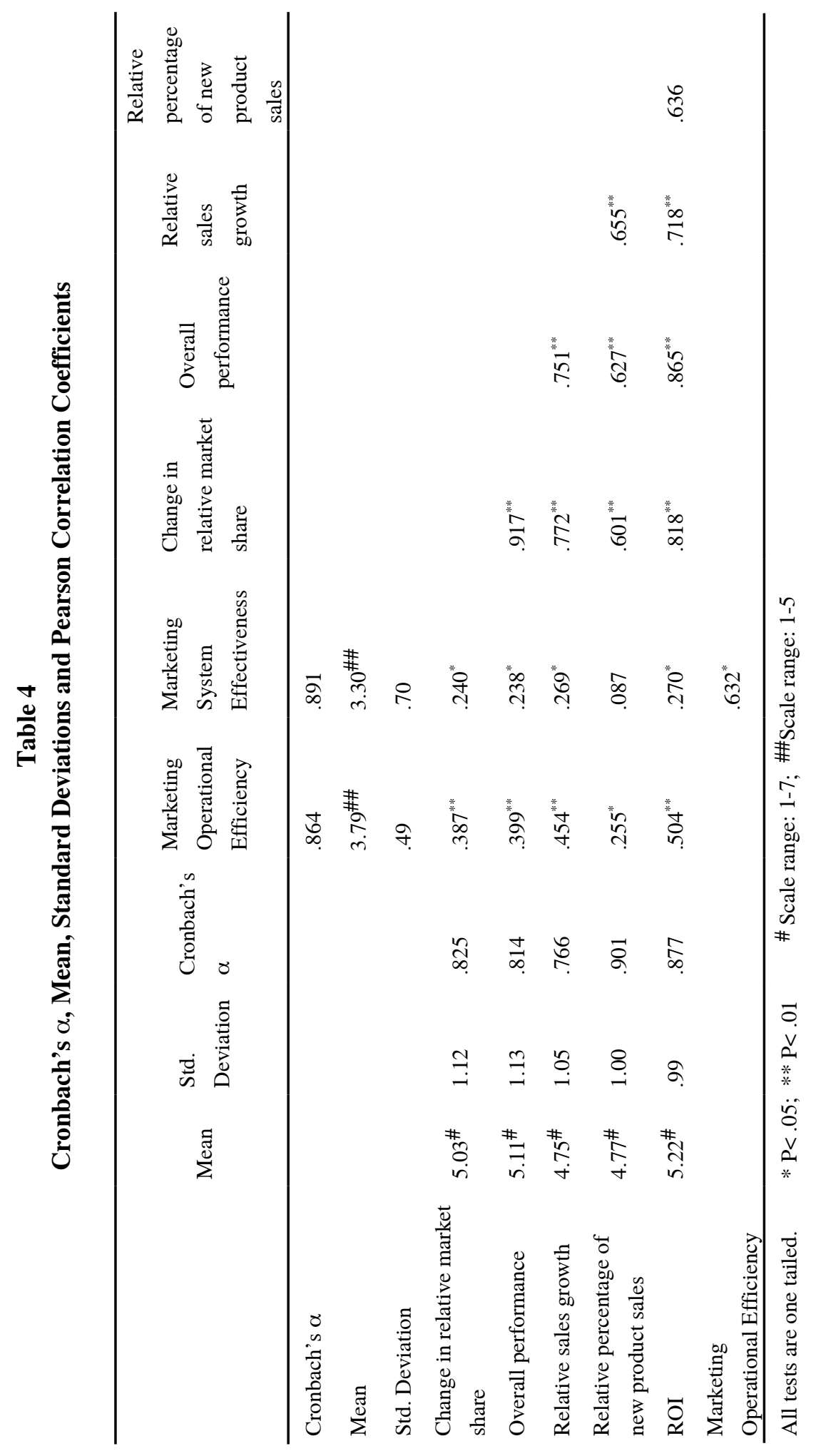




\section{Multivariate Regression Analysis}

The multivariate analyses indicate significant exploratory power for marketing operational efficiency (Wilks' $\lambda=.760, \mathrm{p}<.05$ ), but not for marketing system effectiveness (Wilks' $\lambda$ ). In terms of univariate effects, marketing operational efficiency relates significantly to all performance dimensions. The strongest impact is on profitability (ROI) (effect size $=.200, \mathrm{p}<.05)$, followed by overall performance (effect size $=.145, \mathrm{p}<.05)$, sales growth $($ effect size $=.109, \mathrm{p}<.05)$, market share growth (effect size $=$ $.098, \mathrm{p}<.05$ ), and new product sales (effect size $=.067, \mathrm{p}<.05$ ). On the other hand, marketing system effectiveness, as shown in Table 5, does not relate significantly to any single one of the performance dimensions.

In terms of variances explained in the five dependent performance indicators, as seen in Table 5, the $\mathrm{R}^{2}$ estimate is as follows: .074 for new product sales, .149 for change in relative market share, .160 for relative sales growth, .207 for overall performance, and .258 for ROI.

Table 5

Multivariate Regression Analysis

\begin{tabular}{|c|c|c|c|c|c|c|}
\hline & \multicolumn{3}{|c|}{$\begin{array}{l}\text { Marketing Operational Efficiency } \\
\qquad(\mathrm{F}=4.229, \text { Wilks' } \lambda=.760)\end{array}$} & \multicolumn{3}{|c|}{$\begin{array}{l}\text { Marketing System Effectiveness } \\
\qquad(\mathrm{F}=.280, \text { Wilks' } \lambda=.980)\end{array}$} \\
\hline & $\mathrm{F}$ & Significance & Effect Size* & F & Significance & $\begin{array}{l}\text { Effect } \\
\text { Size* }\end{array}$ \\
\hline $\begin{array}{l}\text { Change in relative } \\
\text { market share } \\
\left(\mathrm{R}^{2}=.149\right)\end{array}$ & 7.673 & .007 & .098. & .003 & 957. & .000 \\
\hline $\begin{array}{l}\text { Overall } \\
\text { performance } \\
\left(\mathrm{R}^{2}=.207\right)\end{array}$ & 12.057 & .001 & .145 & .052 & .821 & .001 \\
\hline $\begin{array}{l}\text { Relative sales } \\
\text { growth }\left(\mathrm{R}^{2}=.160\right)\end{array}$ & 8.699 & .004 & .109 & .029 & .865 & .000 \\
\hline $\begin{array}{l}\text { Relative percentage } \\
\text { of new product } \\
\text { sales } \\
\left(\mathrm{R}^{2}=.074\right)\end{array}$ & 5.106 & .027 & .067 & .708 & .403 & .010 \\
\hline $\begin{array}{l}\text { Return on } \\
\text { Investment } \\
\left(\mathrm{R}^{2}=.258\right)\end{array}$ & 17.741 & .000 & .200 & .383 & .538 & .005 \\
\hline
\end{tabular}

\section{DISCUSSION}

This study contributes to the field in many ways. A deeper understanding of the marketing function firm performance relationship is achieved through observing this relationship by studying marketing 
operational efficiency, a short-term operational view; and marketing system effectiveness, a long-term and strategic view of the system. These two dimensions are analyzed individually. As can be seen in the Appendix, marketing system effectiveness measures the level of planning in the marketing function and amount of time and effort spent actually to understand the market and establish a marketing system. Marketing operational efficiency, on the other hand, studies issues such as how well the marketing department operates, how quickly decisions can be made and implemented, how well different groups work with each other, etc.

The two-factor solution of the marketing effectiveness scale is an interesting finding. Webster's (1995) marketing effectiveness measure was developed in a very different market than that of this research. This could be the reason behind the two-factor solution. According to the results of the exploratory factor analysis, the role and scope of the marketing function is limited. The focus is on marketing management competencies and marketing strategy. This could be due to the fact that the marketing functions are not as developed and central in the Turkish context.

Results suggest that for each performance dimension studied, marketing operational efficiency has a significant impact on firm performance, the strongest impact being on ROI. On the other hand, marketing system effectiveness, while being positively related to most performance dimensions in a bivariate sense, does not seem to impact firm performance dimensions after controlling for efficiency. This finding indicates that how marketing operations, campaigns, etc. are carried out is more important than how the system and strategy is designed as a whole. Considering that our measure of firm performance dimensions is for a 3-year time range (see the Appendix), this rather short-term tendency in findings is to be expected. This tendency could also be a consequence of perceived dynamism, volatility and opportunism in the environment.

Findings further indicate that marketing operational efficiency impacts most strongly on profitability (ROI), followed by sales growth, overall performance, market share growth and new product sales. This finding is rather interesting because one would expect marketing effectiveness, or any of its dimensions, to relate most strongly with market share and sales measures (Megicks and Warnaby, 2008), since ROI is subject to the influence of other, more direct factors than marketing effectiveness, whereas market share and sales measures are more directly linked with marketing effectiveness. Obviously, the cost reduction aspect (the efficient use of resources) plays a more important role than expected in shaping this observed relationship. In other words, it appears that marketing expenses are so high for many of the firms in the sample that even small improvements in the efficiency of marketing operations may have direct and significant impacts on profitability measures.

\section{LIMITATIONS AND DIRECTIONS FOR FUTURE RESEARCH}

There are a few limitations of this study besides its contributions. Sampling procedure used in this study is of a judgmental, purposive nature. Since this is multi-industry sample, industry-specific influences are assumed to be at limited levels. Even though this method of convenience sampling is a valid and acceptable means of sampling for this type of research, the absence of a probability sampling procedure could be considered a limitation. 
Sample size at the firm level can also be considered a limitation in this study. Even though the statistical criteria are met in terms of sample size at the individual respondent level, at the firm level, for the multiple regression analysis method used, the 15-20 observations for each independent variable entering the model criterion (Hair, Anderson, Tatham and Black, 1998) were not met for all of the regressions that were run. Findings that were regarded as "unexpected" in the discussion section may be a result of this limitation.

Also, this study relies on perceptions of the respondents about the behavior of their respective firms. Perceptions are never exact. Especially, in terms of firm performance data, perceptions may be misleading.

This research sheds light on the relationship of marketing system effectiveness and marketing operational efficiency with a number of firm performance indicators. Since this is the information age, future research can be directed towards studying the moderating effect of environmental factors such as technology, e-business, and the Internet on this relationship. Another venue for future research can be a longitudinal look at the constructs of this model and their relationships. Also, further research may be directed towards studying more objective measures of key constructs that are used in this study such as actual firm performance indicators.

\section{CONCLUSION}

This study investigates the influence of marketing operational efficiency and marketing system effectiveness on firm performance dimensions. Marketing operational efficiency and marketing system effectiveness are extracted as two dimensions of marketing effectiveness based on our data, and studied as two separate constructs in this research.

Findings indicate that marketing operational efficiency positively influences all of the firm performance dimensions investigated whereas marketing system effectiveness does not have such an impact. This suggests that managers link short term marketing operational efficiency with firm performance, but do not see longer-term marketing system-related factors as influencers of firm performance.

Findings further indicate that marketing operational efficiency impacts most strongly on profitability (ROI), followed by sales growth, overall performance, market share growth and new product sales. This suggests that the cost reduction aspect (the efficient use of resources) plays an important role in shaping the observed relationship between marketing operational efficiency and firm performance.

\section{REFERENCES}

Appiah-Adu, K., Fyall, A., and Singh, S. (2001). "Marketing Effectiveness and Business Performance in the Financial Services Industry," Journal of Services Marketing, 15(1): 18-32.

Baker, W.E. and Sinkula J.M. (1999). "The Synergistic Effect of Market Orientation and Learning Orientation on Organizational Performance," Journal of the Academy of Marketing Science, 27: 27-411. 
Cameron, K. (1978). "Measuring Organizational Effectiveness in Institutions of Higher Education," Administrative Science Quarterly, 23: 604-632.

Chakravarthy, B. (1986). “Measuring Strategic Performance,” Strategic Management Journal, 6: 437-458.

Churchill, G.A. and Iacobucci, D. (eds.). (2005). Marketing Research: Methodological Foundations. Thomson South-Western.

Clark, B.H. and Ambler, T. (2001). "Marketing Performance Measurement: Evolution of Research and Practice," International Journal of Business Performance Management, 3(2/4): 231-44.

Conant, J.S., Smart, D.T., and Solano-Mendez, R. (1993). “Generic Retailing Types, Distinctive Marketing Competencies and Competitive Advantage," Journal of Retailing, (69): 254-80.

Cooper, R.G. (1979). “The Dimensions of Industrial New Product Success and Failure," Journal of Marketing, 43: 93-103.

Day, R.L. (1977). "Toward a Process Model of Consumer Satisfaction,” in H.K. Hunt (ed.) Conceptualization and Measurement of Consumer Satisfaction and Dissatisfaction: 153-183 Cambridge, Massachusetts: Marketing Science Institute.

Day, G.S., and Fahey, L. (1988). “Valuing Market Strategies,” Journal of Marketing, 52: 45-57.

Doyle, P. (2000). "Valuing Marketing's Contribution," European Management Journal, 18(3): 233247.

Fiorito, S.S., and LaForge, R.W. (1986). "A Marketing Strategy Analysis of Small Retailers," American Journal of Small Business, 5: 83-98.

Greenley, G.E. (1995). "Market Orientation and Company Performance: Empirical Evidence from UK Companies," British Journal of Management, 6: 1-13.

Hair, J.F., Anderson, R.E., Tatham, R.L., and Black, W.C. (Eds.) (1998). Multivariate Data Analysis. Upper Saddle River: Prentice-Hall.

Kotler, P. (1977). "From Sales Obsession to Marketing Effectiveness," Harvard Business Review, 55: 67-75.

Leisen, B., Lilly, B., and Winsor, R.D. (2002). "The Effects of Organizational Culture and Market Orientation on the Effectiveness of Strategic Marketing Alliances," Journal of Services Marketing, 16: $201-222$. 
Matsuno, K. and Mentzer, J.T. (2000). "The Effects of Strategy Type on the Market OrientationPerformance Relationship," Journal of Marketing, 64: 1-16.

Megicks, P. and Warnaby, G. (2008). "Market Orientation and Performance in Small Independent Retailers in the UK," The International Review of Retail, Distribution and Consumer Research, 18(1): 105-119.

Moore, M. and Fairhurst, A. (2000). "Marketing Capabilities and Firm Performance in Fashion Retailing," Journal of Fashion Marketing and Management, 7(4): 386-397.

Narver, J.C. and Slater, S.F. (1990). "The Effect of a Market Orientation on Business Profitability," Journal of Marketing, 5: 20-35.

Nath, P., Nachiappan, S., and Ramanathan, R. (2010). "The Impact of Marketing Capability, Operations Capability and Diversification Strategy on Performance: A Resource-Based View," Industrial Marketing Management, 39: 307-329.

Nwokah, N.G. and Ahiauzu, A.I. (2008). "Managerial Competencies and Marketing Effectiveness in Corporate Organizations in Nigeria," Journal of Management Development, 27(8): 858-878.

O’Sullivan, D. and Abela, A.V. (2007). "Marketing Performance Measurement Ability and Firm Performance," Journal of Marketing, 71(2): 79-93.

O’Sullivan, D., Abela, A.V., and Hutchinson, M. (2009). "Marketing Performance Measurement and Firm Performance,” European Journal of Marketing, 43(5/6): 843-862.

Panigyrakis, G.G. and Theodoridis, P.K. (2009). "Internal Marketing Impact on Business Performance in a Retail Context," International Journal of Retail and Distribution Management, 37(7): 600-628.

Rao, R.K.S. and Bharadwaj, N. (2008). "Marketing Initiatives, Expected Cash Flows, and Shareholders' Wealth," Journal of Marketing, 72(1): 16-26.

Reisberg, G. (1990). "Using Data to Increase Marketing Effectiveness," Sales and Marketing Management Journal, 142: 130-132.

Sapienza, H., Smith, K.G., and Gannon M.J. (1988). "Using Subjective Evaluations of Organizational Performance in Small Business Research," American Journal of Small Business, 13: 45-53.

Slater, S.F. and Narver, J.C. (1994). "Does Competitive Environment Moderate the Market OrientationPerformance Relationship?,” Journal of Marketing, 58: 46-55. 
Van Bruggen, G.H., Lilien, G.L., and Kacker, M. (2002). "Informants in Organizational Marketing Research: Why Use Multiple Informants and How to Aggregate Responses," Journal of Marketing Research, 39(4): 469-478.

Van Egeren, M. and O'Conor, S. (1998). "Drivers of Market Orientation and Performance in Service Firms," Journal of Service Marketing, 12(1): 39-58.

Venkatraman, N. and Ramanujam, V. (1986). "Measurement of Business Performance in Strategy Research: A Comparison of Approaches," Academy of Management Review, 11: 801-814.

Webster, C. (1995). "Marketing Culture and Marketing Effectiveness in Service Firms,“ Journal of Services Marketing, 9: 6-21.

Webster, F. (1988). "The Rediscovery of the Marketing Concept,” Business Horizons, 31: 29-39.

Yilmaz, C., Alpkan, L., and Ergun, E. (2005). "Cultural Determinants of Customer and LearningOriented Value Systems and Their Joint Effects on Firm Performance," Journal of Business Research, 58: $1340-1352$. 


\section{APPENDIX}

\section{Scale Items for Marketing Effectiveness and Firm Performance}

\section{MARKETING EFFECTIVENESS}

Marketing Operational Efficiency

1. Marketing thinking is at the top and is communicated and implemented down the line.

2. Governing board shows good capacity to react quickly and effectively to on-the-spot developments.

3. Governing board is committed to marketing excellence.

4. Governing board is doing an effective job with the marketing resources.

5. Marketing director is working well with other functional directors.

6. The company recognizes the importance of designing the organization to serve the needs and wants of chosen markets.

7. Customer satisfaction is monitored.

Marketing System Effectiveness

8. There exists a whole marketing system view in planning business.

9. There exist efforts expended to measure cost-effectiveness of different marketing expenditures.

10. Regular marketing research of customers, buying influences, etc. is conducted.

11. Formal market planning exists.

12. A high quality marketing strategy exists.

Adapted from Webster, 1995

FIRM PERFORMANCE

\begin{tabular}{ll}
\hline Items & Source \\
\hline
\end{tabular}

1. For your business unit's principal served market segment over the past 3 years, the change in the market share relative to your largest competitor:

Day (1977)

2. Relative to competition, overall performance in your business unit over the past 3 years

Jaworski and Kohli (1993)

3. Your business unit's sales growth relative to major competitors over the past 3 years

Matsuno and Mentzer (2000)

4. Percentage of sales generated by new products over the past 3 years relative to major competitors

Matsuno and Mentzer (2000)

5. Your business unit's ROI relative to major competitors over the past 3 years

Matsuno and Mentzer (2000) 